\title{
THE SUPREME COURT'S JUDGMENT IN MILLER: IN SEARCH OF CONSTITUTIONAL PRINCIPLE
}

\author{
MARK ELLIOTT*
}

\begin{abstract}
In $R$ (Miller) $v$ Secretary of State for Exiting the European Union, the Supreme Court of the United Kingdom (a) held that the UK Government had no prerogative power to initiate the formal process whereby the UK will withdraw from the EU and (b) declined to recognise any requirement that the devolved legislatures' consent be obtained in respect of legislation authorising the Government to commence the withdrawal process. This article critically examines Miller, arguing that the majority's analysis veers between unwarranted muscularity in relation to the prerogative issue and unnecessary conservatism as regards the devolution issue. The article goes on to argue that while the majority judgment's restrictive approach to the prerogative may be viewed as a progressive victory for constitutional principle, such an evaluation can be sustained only if a set of relatively traditional constitutional premises are adopted to begin with. The article also contends that the general approach adopted by the majority is problematic, given its willingness to invoke arguments of constitutional principle without adequately engaging with questions about what the pertinent principles are, and argues that such an intellectually lackadaisical mode of constitutional adjudication is to be deprecated.
\end{abstract}

\footnotetext{
Professor of Public Law, University of Cambridge; Fellow, St Catharine's College, Cambridge. I am grateful to Mikolaj Barczentewicz, John Bell, David Feldman, Timothy Endicott, Tom Fairclough, Aileen $\mathrm{McHarg}$ and the anonymous reviewers for their comments on an earlier draft of this article; to colleagues with whom I have discussed relevant issues - in particular, Paul Daly, Hayley Hooper, Jack Williams and Alison Young; and to Mara Malagodi and John Stanton, who hosted a talk at City Law School in which some of the ideas set out in this article were presented. The usual disclaimer applies.
} 


\section{TABLE OF CONTENTS}

I. Introduction 3

II. The Central Issues $\quad 4$

A. Article 50

B. The prerogative 5

C. The European Communities Act $1972 \quad 6$

III. Constitutional "scale" $\quad 8$

A. The role of "scale" in the majority's reasoning 8

B. The viability of a "scale"-related restriction on the prerogative 9

C. Constitutional "scale" and constitutional principle 10

IV. The domestic legal status of EU law 12

A. EU law as a "direct" and "independent" source of domestic law 12

B. Two analytical vehicles 13

C. The majority's analysis assessed 15

V. Devolution and the Sewel Convention 17

A. The Supreme Court's general approach to conventions 17

B. Law and convention 19

C. The territorial constitution $\quad 21$

VI. The Bigger Constitutional Picture 23

$\begin{array}{ll}\text { A. Introduction } & 23\end{array}$

B. Constitutional principle $\quad 24$

C. Constitutional adjudication $\quad 26$

VII. Miller's Legacy 28 


\section{INTRODUCTION}

By voting to leave the European Union in the referendum that was held on 23 June 2016, the people of the United Kingdom initiated a sequence of events that will have profound social, economic, political, legal and constitutional consequences. The precise nature of those consequences is as yet far from certain. But when in due course they begin to emerge, and the first drafts of the history of "Brexit" come to be written, the decision of the Supreme Court of the United Kingdom in $R$ (Miller) $v$ Secretary of State for Exiting the European Union ${ }^{1}$ will doubtless feature. For a few short months following the referendum, all eyes were on the courts as they determined who had the legal authority to initiate the process by which the UK will withdraw from the EU under Article 50 of the Treaty on European Union ("TEU"). The Court held, by a majority of eight to three, that the Government could not use prerogative power to trigger the withdrawal process. That step, it was held, could be taken only with Parliament's legislative blessing. ${ }^{2}$ That blessing was subsequently conferred by the European Union (Notification of Withdrawal) Act 2017, giving the Prime Minister the power to initiate the Article 50 process - a step that she took on 29 March 2017.

In this way, the Supreme Court staked its claim as one of the dramatis personae in the early chapters of the Brexit story. Yet for future historians seeking to make sense of that story, the Miller judgment might ultimately warrant only a brief mention. After all, involving the Court did not stop Brexit in its tracks. Nor did Parliament take the opportunity to enact legislation limiting the Government's freedom to negotiate the terms of Brexit. For lawyers, however, the significance (or otherwise) of the case does not lie in the political ramifications that it did (or did not) produce. Viewed from the vantage point of constitutional law, questions about where power lies are fundamental. And so, far from acting as the "enemies of the people", as one newspaper ${ }^{3}$ balefully described the judges who decided Miller at first instance, ${ }^{4}$ the case engaged the axiomatic judicial function of determining disputes about how constitutional authority is allocated. That the courts acted entirely properly by deciding the case is therefore beyond question. It does not, however, follow that the same is true of the conclusions that were reached or of the underlying reasoning. This article focusses upon, and takes issue with, three key aspects of the majority judgment.

First, the majority's conclusion regarding the unavailability of the prerogative turned significantly upon its view that "major" constitutional changes can be made only by legislation. Yet that notion lacks support in authority, imports into the law a novel and highly imprecise criterion by which prerogative power is delimited and rests upon normative constitutional foundations that are unarticulated and arguably absent. ${ }^{5}$ Second, the majority held that the prerogative could not be used to initiate Brexit because the EU Treaties and EU legislation are an "independent source" of domestic law. This reasoning does not withstand scrutiny. ${ }^{6}$

\section{1 [2017] UKSC 5, [2017] 2 W.L.R. 583 (hereinafter 'Miller').}

2 The majority consisted of Lord Neuberger, Lady Hale, Lord Mance, Lord Kerr, Lord Clarke, Lord Wilson, Lord Sumption and Lord Hodge. Lord Reed, Lord Carnwath and Lord Hughes dissented.

3 Daily Mail, 4 November 2016, p. 1.

4 [2016] EWHC 2768 (Admin), [2017] 1 All E.R. 158.

${ }^{5}$ See section III below.

${ }^{6}$ See section IV below. 
Third, it was argued that constitutional convention required legislation initiating withdrawal from the EU to be enacted only if the devolved legislatures consented. The Court, however, refused to determine that matter. Whereas it was too quick to invoke questionable arguments of constitutional principle in order to sustain its analysis of the prerogative issue, the majority was arguably too slow to pay heed to the constitutional principles implicated by the devolution issue. $^{7}$

It is possible to paint Miller as an affirmation of fundamental constitutional principle most obviously the sovereignty of Parliament. The executive, after all, was put firmly in (what the majority took to be) its constitutional place. And the sovereign Westminster Parliament was put equally firmly in the driving seat, free from the competing claims represented by (on the one hand) the Government's innate prerogative authority and (on the other hand) the devolved legislatures' asserted rights of constitutional participation. It will be argued, however, that the reasoning that delivered these outcomes reflects an understanding of the constitution that is inadequately subtle, veering as it does between muscular but ill-focussed constitutional assertiveness and unwarranted conservativism. That, in turn, raises questions - which are addressed towards the end of this article ${ }^{8}-$ about the nature of constitutional adjudication and about the contrasting approaches to it adopted by the majority and dissenting Justices in Miller.

\section{THE CENTRAL ISSUES}

\section{A. Article 50}

Central to the issues at stake in Miller is the operation of the process under Article 50 TEU whereby Member States can withdraw from the EU. The first three paragraphs of Article 50 provide as follows:

(1) Any Member State may decide to withdraw from the Union in accordance with its own constitutional requirements.

(2) A Member State which decides to withdraw shall notify the European Council of its intention. In the light of the guidelines provided by the European Council, the Union shall negotiate and conclude an agreement with that State, setting out the arrangements for its withdrawal, taking account of the framework for its future relationship with the Union ... It shall be concluded on behalf of the Union by the Council, acting by a qualified majority, after obtaining the consent of the European Parliament.

(3) The Treaties shall cease to apply to the State in question from the date of entry into force of the withdrawal agreement or, failing that, two years after the notification referred to in paragraph 2, unless the European Council, in agreement with the Member State concerned, unanimously decides to extend this period.

\footnotetext{
${ }^{7}$ See section $\mathrm{V}$ below. In the principal dissenting judgment, Lord Reed concluded that the argument based on convention did not, on his analysis, arise, because, on his view, no legislation to which devolved consent could be given was required: Miller, at [177].
}

${ }^{8}$ See section VI below. 
The structure of Article 50 is such that once notice is served under Article 50(2), a two-year countdown begins. Unless agreement is reached sooner or time is extended by mutual agreement, the withdrawing Member State leaves the EU at the end of the two-year period, whether on agreed terms or simply by dint of the Treaties no longer applying. Thus the default (albeit not the inevitable) consequence of triggering Article 50 is that the EU Treaties cease in due course to apply, depriving those in the UK of currently available legal rights. As the written case for the lead claimant put it, notification amounts to "the pulling of the trigger which causes the bullet to be fired, with the consequence that the bullet will hit the target and the Treaties will cease to apply". ${ }^{9}$ Whether a Member State can withdraw its notification and halt the Article 50 process - thereby returning the metaphorical bullet to the chamber after the gun has been fired - was not determined by the Court, the parties having been content to proceed on the basis that an Article 50 notification is not unilaterally revocable. ${ }^{10}$ It was against this background that the claimant's core point fell to be made: that the consequences of triggering Article 50 were such as to preclude that step from being taken under the prerogative.

\section{B. The prerogative}

In Blackburn v Attorney General, Lord Denning MR said that "[t]he treaty-making power of this country rests ... in the Crown; that is, Her Majesty acting upon the advice of her Ministers". ${ }^{11}$ It followed that "[w]hen ... Ministers negotiate and sign a treaty, they ... exercise the prerogative of the Crown". ${ }^{12}$ This is entirely uncontroversial, and, as Lord Reed observed in Miller, there are "compelling practical reasons for recognising this prerogative power to manage international relations". ${ }^{13}$ It is equally uncontroversial that the treaty-making prerogative extends to the unmaking of treaties. However, it was argued in Miller that that general proposition had to yield in the circumstances of the case. In particular, it was said that it would be incompatible with the European Communities Act 1972 ("ECA") for the prerogative to be used so as to initiate a process whose default consequence would be the loss of EU law rights given effect by the Act. The argument was put in the following terms in an influential blogpost that prefigured the Miller litigation:

The obvious intention of the Act is to provide for the UK's membership of the EU and for the EU Treaties to have effect in domestic law. The purpose of triggering Article 50 would be [to] cut across the Act and render it nugatory. Once a

\footnotetext{
${ }^{9}$ Lead claimant's written case, para. 12.

${ }^{10}$ Although the question of revocability might seem to be key, it is at least arguable that it is a red herring. As G. Peretz, "Will the Supreme Court have to make a reference to the Court of Justice of the EU in Miller?: Further thoughts", Monckton Chambers Brexit Blog, 14 November 2016, argues, even if Parliament could intervene to prevent an Article 50 notification from resulting in Brexit, the fundamental principle remains that "the Royal Prerogative should not be able to remove statutory rights without a positive act by Parliament, namely a specific statutory power or an Act of Parliament". On this analysis, even if the Article 50 notification were unilaterally revocable by the UK, that would not impact upon the question whether legislation is needed to authorise the initiation of the withdrawal process.

11 [1971] 1 W.L.R. 1037, 1040.

12 Ibid., at p. 1040

${ }^{13}$ Miller, at [160]. See also T. Endicott, Parliament and the Prerogative: From the Case of Proclamations to Miller (London: Policy Exchange, 2016).
} 
withdrawal agreement took effect, or if [no] deal was reached, the 1972 Act would be left as a dead letter. ${ }^{14}$

On this view, using the prerogative to trigger Article 50 would offend fundamental constitutional axioms concerning the relationship between prerogative power and the authority of primary legislation, a key implication of latter's priority over the former being that the prerogative cannot be used in a way that is incompatible with statute. That proposition is itself uncontentious; indeed, it is an inevitable corollary of the doctrine of parliamentary sovereignty. From this central insight concerning statute and the prerogative flow several other propositions. As the majority judgment in Miller put it, its "residual nature" means that "a prerogative power will be displaced in a field which becomes occupied by a corresponding power conferred or regulated by statute"; 15 that the prerogative "does not enable ministers to change statute law or common law"; ${ }^{16}$ and that ministers cannot "frustrate the purpose of a statute or a statutory provision, for example by emptying it of content or preventing its effectual operation". ${ }^{17}$ Importantly, however, these propositions could not on their own be determinative of whether the prerogative could be used to trigger Article 50. Rather, the answer to that question turned upon how those propositions applied in the light of two further considerations - namely, the proper interpretation of the ECA and the domestic status of EU law. As we will see, it was their different approaches to these matters that divided the majority Justices and the dissentients - and which revealed a larger fault-line between them, distinguishing two quite different modes of constitutional adjudication.

\section{The European Communities Act 1972}

Whether using the prerogative to invoke Article 50 is precluded by the ECA must turn upon what the ECA relevantly provides. For present purposes, section 2(1) is key:

All such rights, powers, liabilities, obligations and restrictions from time to time created or arising by or under the Treaties, and all such remedies and procedures from time to time provided for by or under the Treaties, as in accordance with the Treaties are without further enactment to be given legal effect or used in the United Kingdom shall be recognised and available in law, and be enforced, allowed and followed accordingly ...

On one reading, section 2(1), and the Act more generally, amounts to a scheme that is predicated upon - in the sense of presupposing and providing for - UK membership of the EU. This view appealed to the majority in Miller, according to which Parliament, by enacting the ECA, "endorsed and gave effect" to UK membership "in a way which is inconsistent with the future exercise by ministers of any prerogative power to withdraw from such Treaties". ${ }^{18}$ On this analysis, while the Act accommodates the varying content of EU law (e.g. through the enactment and revocation of EU legislation) within the context of the UK's membership of the

\footnotetext{
${ }^{14}$ N. Barber, T. Hickman and J. King, "Pulling the Article 50 'Trigger': Parliament's Indispensable Role”, UK Constitutional Law Blog, 27 June 2016.

15 Miller, at [48].

16 Miller, at [50].

17 Miller, at [51].

18 Miller, at [77].
} 
EU, the Act does not accommodate withdrawal. This rules out the use of the prerogative to effect withdrawal, for that would be incompatible with the Act.

An alternative reading of the Act - one that has a good deal in common with an analysis advanced by John Finnis ${ }^{19}$ — was preferred by Lord Reed in his leading dissenting judgment. ${ }^{20}$ According to Lord Reed, the ECA "imposes no requirement, and manifests no intention, in respect of the UK's membership of the EU". ${ }^{21}$ Rather, it amounts to nothing more than a "scheme under which the effect given to EU law in domestic law reflects the UK's international obligations under the Treaties, whatever they may be". ${ }^{22}$ Lord Reed based this analysis in part upon the fact that section 2(1) provides for the domestic legal effect only of such rights as are provided for by the Treaties "from time to time". From this, said Lord Reed, it follows that: "Withdrawal under article 50 alters the application of the 1972 Act, but is not inconsistent with it." ${ }^{23}$ On this view, effecting Brexit will not (as had been suggested) render the ECA "a dead letter", ${ }^{24}$ because it serves simply to give effect to whatever EU obligations, if any, the UK has at any given point in time.

In fact, both the majority and Lord Reed acknowledged that section 2(1) gave effect to a body of EU law of varying content, the scheme of the Act being to enable domestic law to mirror EU law. Thus, as EU legislation is enacted, amended and replaced, so the body of rights given effect by section 2(1) alters. However, unlike the majority, Lord Reed was prepared to go further, by holding that the ECA can accommodate a situation in which, by dint of withdrawal, the body of EU law to which domestic effect falls to be given is non-existent. There was, he said, "no basis in the language of the 1972 Act" for drawing any distinction between "variations in the content of EU law arising from new EU legislation, and changes resulting from withdrawal by the UK from the European Union". ${ }^{25}$ In contrast, the majority concluded that while the Act could accommodate changes to EU law made by the EU institutions or through treaty variation, it could not accommodate the possibility of "complete withdrawal". ${ }^{26}$ Which view is to be preferred?

19 J. Finnis, Brexit and the Balance of our Constitution (London: Policy Exchange, 2016).

20 Lord Reed's is the leading dissenting judgment in the sense that it, unlike any other dissenting judgment, commanded the support of all the other dissentients.

21 Miller, at [177].

22 Miller, at [187].

23 Miller, at [204].

24 Barber et al, note 14 above.

25 Miller, at [187].

${ }^{26}$ Miller, at [81]. 


\section{CONSTITUTIONAL "SCALE"}

\section{A. The role of "scale" in the majority's reasoning}

Lord Reed's analysis might be considered by some to be formalistic. But the charge of formalism (to the extent that it is, in the first place, considered to be a pejorative charge) can be substantiated only if the competing, less "formal", analysis is premised upon an extratextual criterion that is stable and clear enough to serve as a meaningful basis not only for the instant decision, but as a guide to future adjudication, and which (relatedly) is anchored in an underlying principle that is comprehensible and normatively defensible. Judged by this metric, the majority's reasoning falls short. To the extent that the relevant aspect of the majority's analysis can lay claim to intellectual coherence, it might be said to be animated by the notion of constitutional "scale". The majority observed, for instance, that "in constitutional terms the effect of the 1972 Act was unprecedented" and that withdrawal would (necessarily) "constitute as significant a constitutional change as that which occurred when EU law was first incorporated in domestic law by the 1972 Act". ${ }^{27}$ That may well be so. However, the majority concluded that from the empirical fact of the constitutional implications of EU membership (and hence withdrawal) flowed significant legal consequences.

Thus it was said that it would be "inconsistent with long-standing and fundamental principle for such a far-reaching change to the UK['s] constitutional arrangements to be brought about by ministerial decision or ministerial action alone". ${ }^{28}$ And this was no mere throwaway line: the "scale" argument is a recurring theme in the crucial parts of the majority judgment. We are told, for instance, that "a major change to UK constitutional arrangements can[not] be achieved by a ministers alone"; ${ }^{29}$ that such changes can be "effected in the only way that the UK constitution recognises, namely by Parliamentary legislation"; 30 that the fact that withdrawal would effect "a fundamental change in the constitutional arrangements of the United Kingdom" bears decisively upon the question whether "ministers could cause the United Kingdom to withdraw from the EU Treaties without prior Parliamentary approval"; 31 that "the main difficulty with the Secretary of State's argument" is that it "fails to acknowledge the constitutional implications of withdrawal from the EU" which are, because withdrawal is entailed, "fundamentally different" from the implications that would flow from "the abrogation of particular rights, duties or rules derived from EU law"; 32 and that the "loss of a source of law is a fundamental legal change which justifies the conclusion that prerogative powers cannot be invoked to withdraw from the EU Treaties". ${ }^{33}$ The scale of the constitutional change implied by withdrawal from the EU was thus instrumental in leading the majority to the conclusion,

\footnotetext{
27 Miller, at [81].

28 Miller, at [81].

29 Miller, at [82].

30 Miller, at [82].

31 Miller, at [82].

32 Miller, at [81].

33 Miller, at [83].
} 
noted above, that while the ECA accommodates variations in EU law, it should not be construed so as to leave intact prerogative authority to effect withdrawal from the EU. ${ }^{34}$

\section{B. The viability of a "scale"-related restriction on the prerogative}

The criterion of "scale", however, is far from unproblematic. For one thing, it is unclear what, if any, legal pedigree it has. The notion that "major", "fundamental" or "far-reaching" constitutional changes cannot be made via the prerogative was said to follow "from the ordinary application of basic concepts of constitutional law to the present issue". ${ }^{35}$ It is unfortunate, however, that the majority did not see fit to identify those concepts or to show why they generate the prohibition to which they are said to give rise. More generally, if the use of the prerogative really is now constrained not only by established principles but also by its incapacity to do things that have a degree of constitutional significance beyond a given threshold, it becomes necessary to identify precisely where that threshold is located. Yet here, too, the majority judgment offers little by way of guidance, and even less by way of reassurance that the criterion is a serviceable one that is capable of principled and predictable application.

It may be that EU membership and withdrawal are sui generis, and that no other constitutional change that might otherwise be achievable via prerogative power will be prohibited by the majority's criterion of scale. Such a view might be thought to derive some support from the fact that the majority describes the EU Treaties as "unique in their legislative and constitutional implications", citing the fact that "for the first time in the history of the United Kingdom, a dynamic, international source of law was grafted onto, and above, the wellestablished existing sources of domestic law: Parliament and the courts". ${ }^{36}$ But it is clear neither from the judgment nor in principle that this should be considered the sole ground on which a constitutional change might be so significant as to engage the majority's scale-related limitation upon the use of the prerogative. The question thus arises whether the criterion of scale might stymie the use of the prerogative in other contexts.

Consider, for instance, a scenario in which the Government wished to remove the UK from the European Convention on Human Rights ("ECHR") using the treaty-making prerogative, without first legislating to amend or repeal the Human Rights Act 1998 ("HRA"). Could the prerogative be used in such a way, or would Miller preclude this on account of departure from the ECHR being so constitutionally significant as to be unachievable through the use of prerogative power? As far as the structure of the HRA is concerned, there are

\footnotetext{
${ }^{34}$ It is possible to read the majority judgment, at least in places, even more broadly, i.e. as suggesting that the scale argument does not (simply) bear upon questions about how the ECA should be construed, but operates instead as an independent and direct constraint upon the use of prerogative power.

${ }^{35}$ Miller, at [82]. The view that "fundamental" constitutional changes can be made only by Parliament has something in common with the position adopted by the Court of Appeal in $R$ (Jackson) $v$ Attorney General [2005] EWCA Civ 126, [2005] Q.B. 579, in which it was said (at [48]) that certain fundamental changes "could only be enacted or expressly made possible by what is traditionally the sovereign Parliament" rather than under the Parliament Acts 1911-49. However, the House of Lords went on to reject the distinction that the Court of Appeal had sought to draw between fundamental and other constitutional changes: $R$ (Jackson) v Attorney General [2005] UKHL 56, [2006] 1 A.C. 262.
}

${ }^{36}$ Miller, at [90]. 
parallels with the ECA, making the question of ECHR-withdrawal a useful test-bed for the reasoning in Miller. Of particular significance are the facts that: the HRA gives effect only to the "Convention rights"; those rights are defined as certain provisions of "the Convention";37 and "the Convention" means the ECHR "as it has effect for the time being in relation to the United Kingdom". ${ }^{38}$ Thus it is at least arguable that the HRA only protects Convention rights so long as the UK remains a party to the ECHR: if it ceases to be a party, no "Convention rights" exist, because the ECHR no longer has effect in relation to the UK. On the face of it, therefore, the HRA is susceptible to the sort of "ambulatory" interpretation that the Government urged in Miller in respect of the ECA ${ }^{39}$ but which foundered, in no small part, because of the scale of the constitutional change entailed. ${ }^{40}$ Would withdrawing from the ECHR be precluded on the same ground?

The domestic constitutional implications of the ECHR and the HRA are not the same as those of the EU Treaties and the ECA. The ECHR makes no claim to, and the HRA does not seek to ascribe, hierarchical priority to Convention rights within the domestic legal system..$^{41}$ If, therefore, on the analysis of the majority in Miller, recourse to the prerogative is precluded on "scale" grounds only if use of the prerogative would disturb a body of international law that has been accorded domestic primacy, then the scale argument would appear to be inapplicable to the ECHR (and indeed in any other context). However, it would be surprising if the constitutional scale argument uniquely had purchase in relation to the disturbance of law that originates in the international sphere and has primacy over domestic law. If (as we are told by the majority) the principle is that "major" constitutional changes cannot be achieved through the prerogative, then it is surely likely that that category of changes extends beyond the very particular kind of constitutional change that will be brought about by leaving the EU.

\section{Constitutional "scale" and constitutional principle}

Yet the question remains: how are we to identify the content of that category, so as to assist in answering questions such as the one sketched above concerned ECHR-withdrawal? Without explicit guidance from the majority, we might seek instead to infer such guidance from the underlying reasoning. There is, however, regrettably little to go on. "[L]ong-standing and

\footnotetext{
${ }^{37}$ Human Rights Act 1998, s. 1(1).

38 lbid., section 21(1).

39 Miller, at [74].

${ }^{40}$ For a contrasting analysis, according to which the HRA creates "statutory rights" such that withdrawal from the ECHR would not terminate the HRA's capacity to protect Convention rights, see E. Bjorge, "EU rights as British rights", University of Bristol Law School Blog, 14 November 2016. My present purpose is not to assess the merits of these two analyses. Rather, it is to consider whether Miller tells again a reading of the HRA that leaves open the possibility of prerogative-instigated withdrawal from the ECHR.

${ }^{41}$ Indeed, the HRA explicitly eschews any such claim: legislation, including Acts of the UK Parliament, that are found to be incompatible with Convention rights can be declared to be so under section 4(2), but such a declaration, according to section 4(6), "does not affect the validity, continuing operation or enforcement of the provision in respect of which it is given".
} 
fundamental principle" ${ }^{42}$ is invoked, as are "basic concepts of constitutional law". ${ }^{43}$ But what are these principles and concepts? In the absence of explicit indications, the inference might be made, given the prominence accorded to it elsewhere in the judgment, that the majority has in mind parliamentary sovereignty. In UK constitutional law, principles do not get any more fundamental than that. And it is certainly the case that the sovereignty doctrine has considerable normative purchase upon questions about the extent of prerogative power, using such power in a way that would undermine parliamentary legislation being irreconcilable with Parliament's supremacy.

Perhaps, then, the majority's argument is that constitutional changes that somehow offend parliamentary sovereignty are too serious to be effected via the prerogative. But such an argument is problematic. For one thing, it is hard to see what, if anything, it adds to existing principles about the way in which parliamentary legislation limits the prerogative. It is already the case that the prerogative cannot be used contrary to legislation, irrespective of whether the Government seeks to invoke the prerogative for the purpose of effecting major constitutional change. And if the majority intends to suggest that the "major change" principle precludes recourse to the prerogative whether or not that is contrary to legislation, it is hard to see how parliamentary sovereignty can be relevant. After all, the doctrine of parliamentary sovereignty does not ordain that the UK Parliament has, or must have, a monopoly over lawmaking; rather, it is concerned with the legal status of the laws that it does make.

More generally, any argument that seeks to anchor a "major change" restriction on the prerogative in the principle of parliamentary sovereignty risks collapsing into circularity. In Miller, the key question, for present purposes, was whether the ECA should be construed as leaving open the possibility of prerogative-initiated withdrawal from the EU. To suggest that the doctrine of parliamentary sovereignty assists in reaching the conclusion that the ECA should be construed as foreclosing that possibility (because withdrawal is too great a constitutional matter for the prerogative) does no more than beg the question. The sovereignty principle is affronted by the use of the prerogative only if, in the first place, the statute leaves no room for the prerogative to be exercised, raising the question: "What does the statute mean?" The sovereignty doctrine is thus pertinent only insofar as it prevents the prerogative from being used in opposition to the statute: the sovereignty doctrine is the source of the relevant prohibition upon the use of the prerogative, but it cannot be an aid to the interpretive process that determines whether the prohibition is relevant.

Sovereignty thus cannot straightforwardly be the "fundamental principle" that helps to determine whether a constitutional change is too great in scale to be effected via the prerogative. And, if it is not the sovereignty doctrine that performs that role, it is not clear what else it is. It might conceivably be the separation of powers, but that too would be problematic. For one thing, the separation of powers is mentioned nowhere in the majority's judgment. And even if the majority's constitutional scale argument channels without name-checking the separation of powers (in that it reflects that certain, i.e. "major", matters are allocated to the legislative rather than the executive branch) we must once again confront the question of how such matters are to be identified. Just as parliamentary sovereignty cannot assist in that inquiry, neither, arguably, can the separation of powers. The making and unmaking of treaty

\footnotetext{
42 Miller, at [81].

43 Miller, at [82].
} 
commitments is, after all, an executive matter par excellence. And while it ceases to be so if the exercise of the prerogative would be incompatible with statute - an axiom that might be considered to reflect the subservience of the executive to the legislature under the separation of powers - that doctrine, thus conceived, serves as little more than a metaphor for parliamentary sovereignty which, as we have seen, is of limited assistance. The upshot is that the majority's constitutional scale criterion, upon which much of its reasoning hangs, is both highly imprecise and built upon a normative foundation that is, at best, obscure.

\section{THE DOMESTIC LEGAL STATUS OF EU LAW}

\section{A. EU law as a "direct" and "independent" source of domestic law}

If the majority reasoning so far considered is susceptible to criticism on the ground that it is built upon a murky distinction between "major" and other constitutional changes, the same is not true of the other principal aspect of the majority's judgment. Indeed, it invokes a bright-line distinction between things that respectively fall within the scope of the treaty-making prerogative and those that do not. For the majority, the act of triggering Article 50 involves changing domestic law, thereby placing that act in a category that is beyond the reach of prerogative authority. Central to this reasoning is the majority's analysis of the domestic source and status of EU law. The majority concedes that "[i]n one sense" UK law, in the form of the ECA, "is the source of EU law" within the domestic system, because "without that Act, EU law would have no domestic status". ${ }^{44}$ However, without repudiating that analysis, the majority declares it inadequately "realistic", and states its preference for the view that "it is the institutions of the EU which are the relevant source of [EU] law". ${ }^{45}$ Indeed, the majority goes as far as to opine that EU law is "an independent and over-riding source of domestic law" 46 and that "the EU Treaties, EU legislation and the interpretations placed on these instruments by the Court of Justice are direct sources of UK law". ${ }^{47}$

That EU law can take priority over domestic law, including Acts of Parliament, is clear — and has been since the House of Lords' judgment in Factortame (No 2). ${ }^{48}$ However, by stating that EU law is an "over-riding" source of domestic law, the majority implies that EU law necessarily and invariably has priority. Indeed, elsewhere in the majority judgment, it is baldly asserted that EU law has "overriding supremacy in the hierarchy of domestic law sources". 49 This is, putting it mildly, an analysis that lacks nuance, and is hard to reconcile with the Supreme Court's own analysis in the earlier HS2 case. There, the Court concluded that the extent of EU law's effect in the UK is to be determined by reference by the ECA, and that

\footnotetext{
${ }^{44}$ Miller, at [61]

${ }^{45}$ Miller, at [61]

${ }^{46}$ Miller, at [65], [80].

47 Miller, at [61].

${ }^{48} R v$ Secretary of State for Transport, ex parte Factortame Ltd (No 2) [1991] 1 AC 603.

${ }^{49}$ Miller, at [81].
} 
whether EU law has priority over legislative or common law provisions that embody fundamental constitutional values turns upon the proper construction of the ECA. ${ }^{50}$

However, for present purposes, it is the majority's claim that EU law is a "direct" and "independent" source of domestic law that is particularly pertinent. Indeed, this characterisation of EU law's status plays a decisive role in the majority's analysis. For if, as the majority concludes, the EU Treaties and EU legislation are independent, direct sources of domestic law, then the norms that they stipulate are domestic law in precisely the same sense as Acts of Parliament and the common law. On this view, it becomes impossible to resist the conclusion that the prerogative cannot be used to alter or remove EU law - because, even if it is styled "EU law" for the purpose of descriptive convenience, it is, in a taxonomical sense, domestic law. It is therefore inapt to ask whether the ECA has operated so as to constrain the use of the treaty-making prerogative, because in the first place the alteration of domestic law (by excising those of its elements that originated through the UK's membership of the EU) inevitably falls outside the ambit of the prerogative. Moreover, according to the majority, it is not just the case that the prerogative cannot be used to remove or change (what, on their view, is properly to be characterised as) domestic law: neither can the prerogative be used to remove a source of such law. For the majority, then, it follows that

rather than the Secretary of State being able to rely on the absence in the 1972 Act of any exclusion of the prerogative power to withdraw from the EU Treaties, the proper analysis is that, unless that Act positively created such a power in relation to those Treaties [which it did not], it does not exist. ${ }^{51}$

\section{B. Two analytical vehicles}

But is the majority right in the first place to characterise EU law as a source of domestic law, such that the prerogative cannot be used to remove the source and/or to disturb the law that has flowed from it? In answering that question, it is important to be clear that there are two and only two - analytical vehicles that might serve to explain how directly applicable and directly effective EU law ${ }^{52}$ came to have effect within the UK legal system.

${ }^{50} R$ (HS2 Action Alliance Ltd) v Secretary of State for Transport [2014] UKSC 3, [2014] 1 W.L.R. 324. See in particular the judgment of Lord Reed (with which (with which Baroness Hale and Lords Neuberger, Mance, Kerr, Sumption and Carnwath agreed) (at [79]) and the joint judgment of Lords Mance and Neuberger (at [207]) (with which Baroness Hale and Lords Kerr, Sumption, Reed and Carnwath agreed). On the HS2 case, see further M. Elliott, "Constitutional legislation, European Union Law and the nature of the United Kingdom's contemporary constitution" (2014) 10 European Constitutional Law Review 379.

${ }^{51}$ Miller, at [86].

52 I am not concerned here with EU law that secures legal effect in the UK through the enactment of domestic legislation (e.g. secondary legislation made under the ECA, s. 2(2)). When such domestic legislation is enacted, it is that legislation, and not the EU instrument that prefigured its enactment, that has domestic legal effect. In such circumstances, there is no question of EU law constituting domestic law; rather, EU law is the proximate cause of the enactment of law that is, uncontroversially and in the full sense, domestic law. 
The first possibility is one that was notably canvassed by Sir William Wade, according to which the UK's "rule of recognition" may have been altered as a result of EU membership. ${ }^{53}$ On this analysis, EU law falls to be recognised as law in the UK because the rule of recognition - behind which we cannot go, because it owes its authority to no prior rule - so requires. Examining matters in this way enables not just the authority, but also the priority, of EU law to be accounted for, since on this analysis the rule of recognition has adapted not only so as to acknowledge EU law as a source of law but also so as to treat other norms as valid laws only to the extent of their compatibility with EU law. This is not the occasion on which to evaluate attempts to understand EU law's domestic effect by recourse to a change in the rule of recognition. It suffices, for the purpose of the present argument, to observe that none of the Justices who decided Miller relied upon such an analysis. Indeed, it was explicitly repudiated. Having noted that the ECA had wrought an "unprecedented state of affairs" by facilitating EU law's primacy over Acts of Parliament, the majority went on to say that "consistently with the principle of Parliamentary sovereignty ... the 1972 Act can be repealed like any other statute". ${ }^{54}$ The majority continued: "For that reason, we would not accept that the so-called fundamental rule of recognition (ie the fundamental rule by reference to which all other rules are validated) underlying UK laws has been varied by the 1972 Act or would be varied by its repeal." 55

This leaves only one other possible explanation for EU law's applicability within the UK legal system. If the rule of recognition does not acknowledge the EU Treaties and EU legislation as a form of law applicable in the UK, then the domestic applicability of those instruments must instead have been provided for by some norm that is acknowledged by the rule of recognition as a source of law. Lord Reed clearly acknowledged this in his dissenting judgment. In common with the majority, he took the view that "[t]he UK's entry into the EU did not $\ldots$ alter its rule of recognition, and neither would its withdrawal" ${ }^{66}$ However, Lord Reed, unlike the majority, went on unequivocally to acknowledge the logical implication of this conclusion. If EU law did not acquire effect in the UK by virtue of its acknowledgment by the rule of recognition itself, it followed that its effect must be attributable to a form of law that is so acknowledged. ${ }^{57}$ Lord Reed observed that this analysis is consistent with Parliament's own understanding of the position, as set out in the European Union Act 2011, s. 18, according to which directly applicable and directly effective EU law "falls to be recognised and available in law in the United Kingdom only by virtue of" the ECA or other relevant Acts. ${ }^{58}$ Lord Reed also noted $^{59}$ that his analysis was consistent with the analyses advanced by the Supreme Court in the $P h a m^{60}$ and $H S 2^{61}$ cases.

\footnotetext{
${ }^{53}$ H.W.R. Wade, "Sovereignty — revolution or evolution?" (1996) 112 L.Q.R. 568.

${ }^{54}$ Miller, at [60].

55 Miller, at [60].

${ }^{56}$ Miller, at [224].

57 Miller, at [224].

58 Miller, at [227].

59 Miller, at [224]-[225] and [228].

60 Pham v Secretary of State for the Home Department [2015] UKSC 19, [2015] 1 W.L.R. 1591.

${ }^{61} R$ (HS2 Action Alliance Ltd) $v$ Secretary of State for Transport [2014] UKSC 3, [2014] 1 W.L.R. 324.
} 
On this view, EU law is not domestic law in any normal or ultimate sense. Rather it forms a distinct body of law that has effect in domestic law, in the sense of being enforceable in national legal proceedings. As Lord Reed put it: "The 1972 Act did not create statutory rights in the same sense as other statutes, but gave legal effect in the UK to a body of law now known as EU law." 62 And, crucially, as Lord Reed went on to explain, that "body of law" only has such domestic effect as law that really is domestic law provides: "EU law is not itself an independent source of domestic law, but depends for its effect in domestic law on the 1972 Act: an Act which does not confer effect upon it automatically and without qualification, but has to be interpreted and applied in the wider context of the constitutional law of the UK." ${ }^{63}$

From this analysis flow two significant consequences. First, EU law, because it is not domestic law in the normal sense, is not necessarily invulnerable to excision from the domestic legal order by operation of the prerogative. The axiom that the prerogative cannot be used to change domestic law does not bite directly upon EU law if it is not, in the first place, domestic law. Second, the only relevant thing upon which that axiom can bite is the ECA. If the ECA rules out the use of the prerogative for the purpose of effecting EU withdrawal, thereby excising EU law from the domestic legal order, then of course the prerogative cannot be used for that purpose. But that simply takes us back to questions, considered in the previous section, concerning the interpretation of the ECA - in particular, whether it precludes the use of the prerogative for the purpose of effecting withdrawal.

\section{The majority's analysis assessed}

Ultimately, the majority's analysis of the "source of law" issue falls uncomfortably between two stools, and fails to provide a coherent intellectual basis for its argument that the prerogative is necessarily unavailable. The difficulties with its analysis become readily apparent when we confront the four key propositions advanced by the majority on this issue. The propositions are as follows:

(1) The rule of recognition has not changed. ${ }^{64}$

(2) EU law has force in the UK only because of the ECA. ${ }^{65}$

(3) Proposition (2) is insufficiently realistic. ${ }^{66}$

(4) EU law is a direct and independent source of domestic law. ${ }^{67}$

If the central proposition - proposition (4) - is to mean anything, it must surely mean that EU law is a source of law whose status as such is independent of its acknowledgment by other sources of law, such as UK legislation. It is hard, therefore, to see how proposition (4) can stand with proposition (1), given that a source of law can only be independent in the relevant sense if it is acknowledged as a source of law by the rule of recognition. It is also difficult to

\footnotetext{
62 Miller, at [216].

${ }^{63}$ Miller, at [228].

${ }^{64}$ Miller, at [60].

${ }^{65}$ Miller, at [61].

${ }^{66}$ Miller, at [61].

${ }^{67}$ Miller, at [65], [80].
} 
understand how proposition (2) can be reconciled with (3), and how proposition (2) can be reconciled with (4). The majority appears to end up contending that EU law is both dependent for its domestic status upon the ECA (proposition (2)) and an independent source of domestic law (proposition (4)).

There are two ways in which a reconciliation of these propositions might be attempted. The first relies upon a metaphysical sleight of hand, whereby the ECA is capable of rendering EU law an independent source of domestic law while remaining capable of terminating EU law's status as such. But this attempt is doomed to failure. Even if it were somehow possible for the ECA to release the EU law genie from the bottle, thus turning it into an independent source of domestic law, its characterisation as such is meaningless if the repeal of the ECA is capable of returning the genie to the bottle. It is hard to escape the conclusion that if the rule of recognition has not changed, Lord Reed must be right, and EU law's effect in the UK must be attributable to, shaped by, and ultimately dependent upon the ECA.

The second possibility is to conclude that the majority's characterisation of the EU Treaties and EU legislation as "direct" and "independent" sources of law is largely meaningless in legal terms. Rather, on this view, it amounts to little more than a rhetorical flourish or descriptive insight - in the sense that it describes the reality that the EU makes laws that have effects in the UK. But if the point goes no further than this, then it has no bearing upon the domestic legal status of EU law, leaving that question to be answered wholly by reference to the proper construction of the ECA. It follows that while understanding the majority's "source of law" argument in this limited way carries the benefit of rescuing it from incoherence because it is no longer forms part of a set of flatly contradictory claims - it does so at the cost of emptying the argument of legal significance.

Indeed, if all that the majority is actually offering is an empirical observation that the laws given effect by the ECA are produced by the EU, and that closing off that source of production would have important consequences, then its "source of law" analysis becomes little more than a version of its "constitutional scale" argument. On this view, however, the notion that EU law is a direct and independent source of domestic law ends up being far from the slam-dunk argument that the majority presupposes. Instead, it remains the case that EU law is - as Lord Reed unequivocally recognises - a body of law that has whatever domestic effect is provided for by the ECA and whatever domestic status it is accorded by that legislation. If the descriptive status of the EU Treaties and EU legislation as a "source of law" is somehow relevant to the construction of the ECA - because, for instance, it is felt to buttress the argument about the scale of the constitutional change implied by withdrawal then so be it. It is far from clear, however, that the "source of law" argument, to the extent that it can be understood as a coherent one, is capable of adding any independent value to the majority's analysis. 


\section{DEVOLUTION AND THE SEWEL CONVENTION}

\section{A. The Supreme Court's general approach to conventions}

When Miller was decided by the Divisional Court, the focus was squarely on the issues addressed in sections II-IV of this article. However, by the time the case reached the Supreme Court, the constitutional lens being applied had broadened considerably. For one thing, the Supreme Court was required to determine devolution issues referred to it from Northern Ireland, including in the context of litigation that had taken place there in the High Court. ${ }^{68}$ In addition, devolution arguments were raised before the Supreme Court by intervening parties - including, on behalf of the Scottish and Welsh administrations respectively, the Lord Advocate and the Counsel General for Wales. The application of this wider lens had at least the capacity to produce a substantially different constitutional image. Viewed thus, the case ceased to be concerned exclusively with a familiar - though, in this context at least, vexed - question about the demarcation of legislative and executive authority, and extended to the relationship between different loci of authority within the UK's multi-layered territorial constitution.

That is not, however, to deny that the devolution issues raised before the Supreme Court overlapped to some extent with those considered earlier in this article. For instance, the Court was asked to determine whether, like the ECA, the Northern Ireland Act 1998 ("NIA") precluded recourse to the prerogative for the purpose of invoking Article 50. The majority observed that the NIA had "conferred rights on the citizens of Northern Ireland" by equipping them to challenge executive and legislative action on the ground of incompatibility with EU law. ${ }^{69}$ The majority went on to say - in line with the reasoning it had deployed in respect of the ECA - that since "it is normally impermissible for statutory rights to be removed by the exercise of prerogative powers in the international sphere", it would be "incongruous if constraints imposed on the legislative competence of the devolved administrations by specific statutory provisions were to be removed, thereby enlarging that competence, other than by statute". ${ }^{70}$ The majority did not, though, go beyond this observation, saying that its conclusion regarding the ECA made it unnecessary to reach "a definitive view" about whether the NIA imposed "a discrete requirement for Parliamentary legislation". ${ }^{71}$

However, in addition to these arguments about the interaction of the prerogative with the NIA — and, implicitly, with the other devolution legislation — the Court was also confronted with a different kind of devolution-related question. Given that - in the light of the majority's stance on the prerogative issue - primary legislation was required before notice could be served under Article 50(2), was it necessary to secure the consent of the devolved legislatures to such legislation? At the core of this question lies the Sewel convention, which is recorded

\footnotetext{
68 Re McCord, Judicial Review [2016] NIQB 85.

69 Miller, at [131].

${ }^{70}$ Miller, at [132].

${ }^{71}$ Miller, at [132].
} 
in a Memorandum of Understanding between the UK and devolved governments ${ }^{72}$ as well as in the Cabinet Manual. ${ }^{73}$ According to those sources, the convention is that "the UK Parliament would not normally legislate with regard to devolved matters except with the agreement of the devolved legislature". Such written statements cannot, however, be authoritative in the way that legislation can be decisive as to what the law is. Constitutional conventions can and do evolve, and the Sewel convention is now generally understood in terms that are broader than those in which it is set out in the Memorandum of Understanding and the Cabinet Manual. In particular, it is taken to extend, at least in relation to Scotland and Wales, not only to UK legislation that deals with matters that have been devolved, but also to UK legislation that determines the scope of what is devolved. ${ }^{74}$ Crucially, as the majority pointed out in Miller: "The removal of the EU constraints on withdrawal from the EU Treaties will alter the competence of the devolved institutions unless new legislative constraints are introduced." 75 It followed that, without such new constraints, withdrawal would "enhance" devolved competence. ${ }^{76}$ This raised the question of whether devolved consent to legislation initiating withdrawal was required by the Convention.

But the Court refused to answer that question. Judges, it was said, "are neither the parents nor the guardians of political conventions; they are merely observers". This meant that while courts "can recognise the operation of a political convention in the context of deciding a legal question", it was not open to them to "give legal rulings on its operation or scope". Those matters, it was said, were determined in "the political world". ${ }^{77}$ Since it was, on this view, constitutionally improper for the Court to decide whether the Sewel convention applied, there could be no question of the Court enforcing the convention. But for good measure, the majority made it perfectly clear that there was no possibility of enforcement anyway. In doing so, the majority endorsed the view of the Supreme Court of Canada that: "The very nature of a convention ... is inconsistent with its legal enforcement."78

The adoption in Miller of this view of the role of conventions is arguably as significant - at least in terms of what it tells us about the Supreme Court's understanding of the contemporary constitution - as the stance it took on the relationship between the ECA and the prerogative. This is so because of both its general implications for the relationship between

\footnotetext{
72 Memorandum of Understanding and Supplementary Agreements between the United Kingdom Government, the Scottish Ministers, the Welsh Ministers, and the Northern Ireland Executive Committee (2013), p 8.

73 Cabinet Manual (2010), p 64.

${ }^{74}$ See Department for Constitutional Affairs, Devolution Guidance Note 10: Post-Devolution Primary Legislation affecting Scotland; Wales Office, Devolution Guidance Note 17: Modifying the Legislative Competence of the National Assembly for Wales. No equivalent provision is made in respect of Northern Ireland: Devolution Guidance Note 8: Post-Devolution Legislation Affecting Northern Ireland.

75 Miller, at [130].

76 Miller, at [130].

77 Miller, at [146].

78 Miller, at [141] citing Re Resolution to Amend the Constitution [1981] 1 SCR 753, 774-775 (Laskin CJ and Dickson, Beetz, Estey, Mclntyre, Chouinard and Lamer JJ).
} 
law and convention and its implications for the nature of the territorial constitution. Those two points will be developed in turn.

\section{B. Law and convention}

The Court's view of the role of constitutional conventions - and of their relationship with law - is notably conservative. Judicial reticence in respect of convention chimes, of course, with Diceyan orthodoxy, and the notion that courts cannot enforce conventions is generally, albeit not universally, ${ }^{79}$ accepted. But to suggest that courts cannot rule on the "operation" or "scope" of conventions is to take a strikingly narrow view of the proper extent of judicial engagement with conventions. Three issues arise.

First, Miller sits uncomfortably with existing case law. For instance, in Evans, the Upper Tribunal engaged in notably detailed analysis of conventions pertaining to the constitutional role of the heir to the throne. It did so in the course of determining - as was required by the Freedom of Information Act 2000 - whether the public interest favoured disclosure of Prince Charles's "advocacy correspondence" with Ministers. ${ }^{80}$ The Tribunal concluded that while "the heir to the throne is entitled and bound by constitutional convention to be educated in and about the business of government", ${ }^{81}$ the "education convention" did not extend to engagement by the heir in advocacy concerning his views on matters of public policy. In reaching this view, the Tribunal recognised that it was "decid[ing] the extent of the constitutional convention". ${ }^{82}$ And while it acknowledged that a court or tribunal "only rarely" has to undertake such a task, and that it was a task that should be undertaken "with circumspection", ${ }^{83}$ those considerations did not deter the Tribunal from determining that the matters before it fell outwith the convention's scope.

A similar point can be made in respect of the Jonathan Cape case, in which the court took into account (and took a view about the scope of) the convention of Cabinet responsibility in determining a legal question concerning breach of confidence. ${ }^{84}$ Indeed, Lord Widgery C.J. found that there was "overwhelming evidence that the doctrine of joint responsibility is generally understood and practised" as well as "equally strong evidence that it is on occasion ignored". ${ }^{85}$ This led him to the conclusion that "the doctrine is an established feature of the English form of government, and it follows that some matters leading up to a Cabinet decision may be regarded as confidential". ${ }^{86}$

\footnotetext{
(Oxford 2013), ch. 2.

${ }^{80}$ Evans v Information Commissioner [2012] UKUT 313 (AAC).

81 Ibid., [64].

82 Ibid., [68].

83 lbid., [68].

${ }^{84}$ Attorney-General v Jonathan Cape Ltd [1976] Q.B. 752.

85 Ibid., p 770.

86 Ibid., p 770.
}

79 For contrasting views on enforceability, see J. Jaconelli, "Do Constitutional Conventions Bind?" [2005] CLJ 149 and T.R.S. Allan, The Sovereignty of Law: Freedom, Constitution and Common Law 
Second, the foregoing point, taken on its own, would be of limited value. It is, after all, open to the UK Supreme Court to take a view that is at odds with the judgments of lower courts and tribunals - albeit that one might reasonably expect the Court to acknowledge and justify its departure from their jurisprudence. However, the willingness of those other bodies to grapple with questions concerning the operation and scope of conventions serves to highlight not merely a point of distinction with the Miller judgment, but also a fundamental tension within it. As already noted, the majority acknowledges that courts can recognise the operation of a political convention in the context of deciding a legal question. It stands to reason, however, that if conventions are to play a meaningful role in the resolution of legal questions to which they are pertinent, the court may well have to take a view about how the convention works and what its scope is. The Court cannot have it both ways. If the judicial role really is as limited as the majority contends, such that courts will retreat whenever issues pertaining to conventions are contested, then the notion that conventions can be taken into account when determining relevant legal questions is largely emptied of content.

That leads on to a third point — that the highly constricted judicial role vis-à-vis conventions which the Supreme Court envisages is normatively dubious. The approach adopted in Miller risks marginalising conventions' role in constitutional adjudication: as already observed, if courts are to walk away from questions about conventions whenever answering them would require determination of their operation or scope, courts will engage with conventions rarely. To proceed in such a way would risk the impoverishment of constitutional adjudication. Conventions can, and often do, amount to the crystallisation in tangible form of fundamental constitutional principles. The Sewel convention is a case in point. Its practical incentivisation of a form of institutional comity reflects an underlying normative reality - that devolution's technically "top-down" nature notwithstanding, the modern territorial constitution is premised upon constitutional actors' mutual respect for each other's constitutional spheres of authority. In this way, constitutional conventions have the potential to inform, and perhaps on occasion decisively affect, the determination of legal-constitutional disputes by enabling norms that receive recognition primarily through convention to shape relevant legal analysis.

It might be argued that the Court's unwillingness to engage with the Sewel convention is justifiable because the determination of the issues relating to it were not necessary for the purpose of resolving the legal question before the Court. There is some mileage in that argument: the resolution of the legal question ("Was legislation needed?") bore upon the question whether the Convention was engaged, but the latter did not bear upon the former. However, this point is not a complete answer to the position adopted by the Court in respect of the Sewel convention. For one thing, the convention was arguably directly relevant to the legal question as to what would constitute a decision by the UK to leave the EU "in accordance with its own constitutional requirements". ${ }^{87}$ For instance, the Lord Advocate argued, on behalf of the Scottish Government, that: "The 'constitutional requirements', according to which a decision to withdraw from the EU must be taken, ... include (i) the legal requirement for an Act of the UK Parliament; and (ii) [compliance with] the Legislative Consent Convention." 88 In its judgment, the Court did not take a position as to the correctness of this submission, the focus of the litigation (curiously) having been upon the lawfulness of serving notice under Article $50(2)$, rather than upon the question whether, in the first place, a valid "decision" had been

87 TEU, Article 50 (1).

${ }^{88}$ Written case of Lord Advocate, paragraph 85. 
taken under Article 50(1) in accordance with relevant "constitutional requirements". But the Lord Advocate's submission serves to highlight the broader point that the Court's unwillingness to determine questions relating to the operation and scope of conventions largely undercuts its assertion that conventions can be "recognise[d]" by courts "in the context of deciding a legal question". ${ }^{89}$ On the Court's view, even if the Lord Advocate's argument had been considered, it would have been impossible to determine its correctness, because that would have required the Court first to take the impermissible step of deciding upon the scope and operation of the convention.

It follows that even if the Court's refusal to resolve questions about the Sewel convention is defensible on the ground that such questions were not pertinent to a legal matter that was directly in issue, the Court's general approach to conventions in Miller suggests that the scope for examining legal questions in the light of relevant conventions is heavily constricted. And therein lies a paradox: while the majority was prepared to invoke unarticulated constitutional principles in defence of its view that the prerogative could not be used to effect "major" changes or remove or a "source of law", the position it adopted in relation to conventions is liable to have the effect of marginalising the role that such conventions and the often fundamental principles that animate them - can play in constitutional adjudication.

\section{The territorial constitution}

The discussion so far presupposes that the Sewel convention is precisely that - a convention. However, the position is (it might be thought) complicated by the statutory reference to the substance of the convention now found in the Scotland Act 1998. Section 28(7) of that Act avers that: "This section" - which invests the Scottish Parliament with law-making authority - "does not affect the power of the Parliament of the United Kingdom to make laws for Scotland." However, thanks to the Scotland Act 2016, section 28(7) of the 1998 Act is now glossed by section 28(8). It says, in language that tracks the convention, that "it is recognised that the Parliament of the United Kingdom will not normally legislate with regard to devolved matters without the consent of the Scottish Parliament". Section 2 of the Wales Act 2017 which was not in force when Miller was decided - inserts a new section 107(6) into the Government of Wales Act 2006, making substantially identical provision in respect of Wales.

This statutory acknowledgment of the substance of the Sewel convention notwithstanding, the Court concluded that it remained nothing more than a convention. In particular, it was held that the UK Parliament, by inserting section 28(8) into the Scotland Act 1998, had not been "seeking to convert the Sewel Convention into a rule which can be interpreted, let alone enforced, by the courts". ${ }^{90}$ Rather, it had been "declaring that [the convention] is a permanent feature of the relevant devolution settlement" ${ }^{1}$ and "entrench[ing] it as a convention". ${ }^{92}$ This analysis of what Parliament was trying to do is far from straightforward. It is, for instance, unclear what is entailed by the "entrenchment" of a

\footnotetext{
89 Miller, at [146].

90 Miller, at [148].

91 Miller, at [148].

92 Miller, at [149].
} 
convention, or in what sense the convention is rendered "permanent" by section 28(8). If the Sewel convention continues to be nothing more than a convention, then its normative source lies outside any legislation, and it remains a product of political consensus. If that consensus develops (or breaks down) then the convention will evolve (or disintegrate). The convention, if that is all it is, cannot therefore straightforwardly be entrenched or otherwise made permanent by reference to it in legislation. That said, it is of course arguable that such reference may serve at some level as evidence of a political commitment to the convention. Even then, however, the statutory reference must be of limited import if the Sewel convention remains no more than that, given that legislation enacted in 2016 (in respect of Scotland) and 2017 (in respect of Wales) can be evidence only of political commitments that existed at those points in time.

While the Court's analysis of the (very limited) effect that section 28(8) does have is vague, its stance on the effect it does not have is much clearer. In particular, the Court held that section 28(8) does not turn the Sewel convention into a legal restriction upon the legislative capacity of the UK Parliament. On this point, the Court is surely correct. For one thing, it far from clear that the UK Parliament is capable of limiting its authority in such a way. But, leaving that point to one side, it is tolerably clear that that is not what was intended. In particular, by prefacing its reference to the substance of the convention with the words "it is recognised", section 28(8) makes plain that it is merely acknowledging the existence of the convention, rather than legislatively transforming it into a legal requirement. The Court thus adopted an entirely defensible position when it said that it "would have expected [the] UK Parliament to have used other words if it were seeking to convert a convention into a legal rule justiciable by the courts". ${ }^{93}$

However, while the Court's legal analysis of this point is sound, it lays bare the smokeand-mirrors exercise to which section 28(8) of the Scotland Act 1998 - and now section 107(6) of the Government of Wales Act 2006 - reduces. It is, of course, unlikely that the UK Government expected the legal effect of those provisions to be judicially tested - and their legal redundancy so amply demonstrated - so soon after their enactment. Yet that is precisely what Miller does. Indeed, the UK Government conceded as much in its written argument, referring to the "legal irrelevance" of the Sewel Convention, ${ }^{94}$ reasserting that "the Westminster Parliament is sovereign and may legislate at any time on any matter", ${ }^{95}$ and arguing that "[n]othing in that analysis is affected" by section $28(8) \cdot{ }^{96}$ By adopting this view, the Court demonstrates that the new provisions acknowledging the convention amount to nothing more than political tokens dressed in legislative garb. It follows that, when push comes to shove, the political niceties of institutional comity reflected in the Sewel convention founder upon the hard legal rocks of (Westminster's) legislative supremacy, the window-dressing supplied by sections $28(8)$ and 107(6) of the respective devolution statutes notwithstanding.

\footnotetext{
93 Miller, at [148].

94 Appellant's Written Case on the Devolution Issues, para. 24.

95 Ibid., para. 31.

96 lbid., para. 33.
} 


\section{The Bigger Constitutional Picture}

\section{A. Introduction}

Miller is doubtless one of the most-discussed cases of recent times. Indeed, the level of debate that it stimulated among commentators well before judgments were given by either the Divisional Court or the Supreme Court is probably unparalleled. ${ }^{97}$ The volume of discussion precipitated by the case can be attributed in part to a combination of the significance of the legal-constitutional issues raised by it and the political crucible in which they fell to be determined during the immediate aftermath of referendum. However, the amount of debate that took place is also a function of the level of disagreement that the case stimulated, several aspects of which are reflected, at least to some extent, in the contrasting judgments given in the Supreme Court. Why, then, did the case prove to be so intellectually divisive? And what does the fact that it provoked so much controversy tell us about its wider constitutional significance?

Shorn - as, for the purpose of legal analysis, it must be - of the extraordinary political circumstances in which it was decided, Miller is in one sense an unlikely candidate for the degree of disagreement it excited. The central question that the Court had to determine can be framed in relatively straightforward terms (even if the substance of the question turned out to be less than straightforward). The question, in essence, concerned whether - and, if so, how - a statutory provision operated upon the Crown's treaty-making prerogative. Moreover, the constitutional ground-rules governing the interoperation of statute and prerogative are relatively settled, and were not the subject of significant disagreement between the majority and minority judges in Miller. Why, then, did the issues raised by the case attract such controversy? For one thing, the ECA, thanks to its opaque drafting, raised particularly difficult and uncertain questions of statutory interpretation. Meanwhile, although the constitutional ground-rules concerning the relationship between statute and prerogative were themselves relatively uncontentious, the hinterland of constitutional principle by reference to which those ground-rules fell to be applied - and, crucially, in the light of which the ECA had to be construed - was far more contestable and uncertain in nature.

In the light of these considerations, it is possible to step back from the technical particularities of Miller and to ask some broader questions about the underlying causes of the disagreement between the majority and dissenting judges (and about the causes of the discord evidenced by the wider debate about Miller). Those causes lie in two principal (and related) factors - namely, the range of constitutional principles that are relevant and the style of constitutional adjudication via which those principles are judicially curated.

\footnotetext{
${ }^{97}$ At least when judged in terms of published debate. That debate played out in a wide variety of fora, but nowhere more notably than in the pages of the UK Constitutional Law Association Blog <https://ukconstitutionallaw.org/blog/>.
} 


\section{B. Constitutional principle}

It might well be argued that the majority judgment is progressive in nature, striking, as it does, a blow against the anachronistic prerogative powers of the Crown and focussing authority in a democratic legislative institution. Miller can thus be characterised as a victory for Parliament over the executive: of the prioritisation of considerations of democracy and accountability and, in that loose sense, as a reaffirmation of parliamentary sovereignty itself. It might, of course, be retorted that in the end the European Union (Notification of Withdrawal) Act 2017 - the enactment of which was necessitated by the majority's insistence upon parliamentary legislative involvement - was something of a damp squib, Parliament having signally failed to take the chances it was afforded to shape the Government's negotiating position and secure Parliament's own role in respect of the exit process. But such criticism, while politically highly pertinent, is legally and constitutionally insubstantial, the crucial point being that the Miller judgment gave Parliament the chance to have democratic input and insist upon oversight.

Thus one way of characterising the fissure between the judgments in Miller - and the broader positions for which they stand - is in terms of their progressiveness, the majority's judgment standing in contrast to what might be regarded as the more conservative approach of Lord Reed. However, any attempt to analyse Miller in this way must be undertaken with caution. From a different perspective - which goes to the range of constitutional principles taken to be implicated by the case - the majority judgment arguably takes on a different complexion. Indeed, it can be argued that Miller is (paradoxically) lent a progressive air only if it is in the first place viewed through a relatively traditional lens - one that postulates constitutional adjudication in terms of the refereeing of a zero-sum game in which Westminster and Whitehall are the sole participants. Examined thus, the majority's prioritisation of Parliament's role, given its credentials of democratic representativeness and accountability, has an evident constitutional-normative appeal. But viewing the contemporary constitution in this way is liable to yield an incomplete picture of it. As Miller itself so clearly illustrates, the British constitution is today a far more complex decisional space - in which the electorate, through referendums, and devolved legislatures and administrations play a role - than can be accommodated by an analysis that simply pits the Westminster Parliament and the central government against one another, with courts serving as honest brokers. That much is apparent when one considers the broader constitutional backdrop against which Miller must be viewed.

To begin with, there is the referendum itself. A bald, prerogative-based constitutional power grab by the executive at the expense of Parliament is one thing. But the constitutional offensiveness of using prerogative power in the circumstances with which Miller was concerned cannot sensibly be evaluated without reference to the fact that such power would have been being deployed so as to implement the outcome of a referendum that constituted one of the largest democratic exercises ever undertaken in the UK, and which, in the first place, had been provided for by Parliament through primary legislation. Meanwhile, the rigidity of the distinction drawn by the majority judgment between legal and political elements of the constitution yielded an outright refusal to engage with any questions concerning the Sewel convention - which, as we have seen, institutionalises a fundamental principle governing the operation of the contemporary territorial constitution. That the Court did not engage with the referendum or the convention are not themselves grounds for arguing that it went straightforwardly wrong as a matter of law. But they do serve to demonstrate that the legal issues addressed by the Court in Miller formed only a subset of the constitutional issues that were at stake. 
If, then, Miller represents a victory for constitutional principle in general, and for the principle of parliamentary sovereignty in particular, then it reduces to a victory for a particular understanding of the constitutional order. Of course, the nature of the UK's constitution is such that there has always been a distinction between its legal and its political aspects, such that the answers to legal-constitutional questions may be at odds with, or may fail to take account of, elements of the constitution that form part of its political limb. But Miller throws that distinction into sharp relief, the Court's focus having been exclusively on the demarcation of authority as between the UK Parliament and Government, without reference to the fact that - as is increasingly common - a referendum had taken place, and without reference to the participative constitutional claims advanced by the devolved institutions.

This article has levelled a number of criticisms at the majority judgment. That the majority did not straightforwardly conclude that the referendum overrode the claimant's argument or that the Sewel Convention legally disabled the UK Parliament from legislating absent devolved consent are not among those criticisms, for such criticisms would be far too blunt. But those broader aspects of the case - which were not, and could not be, accommodated by an analysis predicated upon orthodox constitutional principle - give pause for thought when we turn our minds to the future trajectory of the UK constitution. The Divisional Court, in its judgment in Miller, gave a ringing endorsement to Dicey's statement that: "The judges know nothing about any will of the people except in so far as that will is expressed by an Act of Parliament, and would never suffer the validity of a statute to be questioned on the ground of its having been passed or being kept alive in opposition to the wishes of the electors." 98 It would be rash to suggest that this tenet of orthodoxy should simply be abandoned in the face of a referendum, and "popular will" accorded free rein over the statute book. But increasing recourse to referendums as constitutional devices raises basic (yet profound) questions about the relationship between parliamentary and popular sovereignty - and about whether the normative claim exerted by the former must be viewed in the light of the extent of the normative claim made by the latter. If the sovereignty of Parliament is the central constitutional principle upheld by the majority judgment in Miller, and thus served as a basis for interpreting the ECA as the majority did, then the question at least arises whether the contours and demands of that principle fall to be evaluated in the light not of some inchoate notion of "the will of the people", but in the light of the outcome of a referendum that Parliament itself provided for.

Meanwhile, the disjunction between the legal doctrine of parliamentary sovereignty and the constitutional division of authority between governing institutions at the UK and devolved levels necessarily renders incomplete any adjudicative model that views the constitution through an exclusively legal lens. Fundamental constitutional principle cannot be remade overnight. But Miller nevertheless ought at least to trigger reflection upon the extent to which such principle is, or ought to be, cast in a new light by the contemporary nature of the constitutional order. Miller may thus on one analysis be considered a progressive blow against the archaism of Crown prerogative. Yet it might simultaneously be said to amount to a defence of a rather traditional approach that superimposes upon a multilateral constitutional order a vision of it that is myopically bilateral in nature.

98 [2016] EWHC 2768 (Admin), [2017] 1 All E.R. 158, [22]. 


\section{Constitutional adjudication}

As noted in the previous section, one benchmark by reference to which the decision in Miller might be judged relates to the range of constitutional principles that are drawn upon; depending upon what we think the operative principles are, or should, be, the majority's stance might appear more or less progressive. A distinct (albeit related) perspective from which Miller might be evaluated concerns whatever one considers the proper qualities and characteristics of constitutional adjudication to be. It might be suggested - and indeed it has been argued ${ }^{99}$ - that the majority and dissenting judgments in Miller reflect a broad distinction between form and substance. Viewed through this optic, the two approaches - depending on one's underlying view - might be the subject of praise or criticism. For instance, Lord Reed might be congratulated for the logical punctiliousness of his analysis, or castigated for adopting a narrowly technical perspective that overlooks the enormity of what is at stake. (It will be noted that if one regards the latter as a pertinent criticism, then one implicitly endorses the majority's "constitutional scale" analysis.) Meanwhile, the majority might be condemned for an intellectual sloppiness that prizes over rigorous analysis an outcome that feels instinctively "right" — or it might be praised for conjuring a constitutional wood from the trees.

That such different perspectives can be brought to bear upon the Miller case hardly renders it unique. The Supreme Court's judgment in Evans invites - at least superficially the drawing of similar distinctions. ${ }^{100}$ That case concerned the scope and exercise of the Government's "veto" power ${ }^{101}$ over decisions of the Upper Tribunal about the disclosure of information under the Freedom of Information Act 2000. Giving one of the majority judgments, Lord Neuberger, with whom Lords Kerr and Reed agreed, ${ }^{102}$ adopted an approach to the veto power that disclosed anything but a formal approach. Indeed, so radical was the interpretive surgery that they performed upon the legislation that Lord Wilson, in his dissent, said that they "re-wrote" the veto provision. ${ }^{103}$ However, in one important respect, the fault-lines that separate the different judicial approaches found in Evans are distinct from those that are found in Miller. In Evans, the constitutional principles that were in play were clear, but the relative weight to be accorded to them was contested. At the risk of oversimplification, ${ }^{104}$ Lords Neuberger, Kerr and Reed assigned great weight to rule of law and separation of powers considerations that told against a wide executive power to override the judgments of an

99 See, e.g., P. Daly, "Brexit: Legal and Political Faultlines", Administrative Law Matters, December 2016 <http://www.administrativelawmatters.com/blog/2016/12/06/brexit-legal-and-political-faultlines/>; A. Young, " $R$ (Miller) $v$ The Secretary of State for Exiting the European Union [2016] EWHC 2768 (Admin): Constitutional Adjudication — Reality over Legality?", UK Constitutional Law Association Blog, November 2016 <https://ukconstitutionallaw.org/2016/11/09/alison-young-r-miller-v-the-secretary-ofstate-for-exiting-the-european-union-2016-ewhc-2768-admin-constitutional-adjudication-reality-overlegality/>.

$100 R$ (Evans) v Attorney General [2015] UKSC 21, [2015] A.C. 1787.

101 Freedom of Information Act 2000, s. 53(2).

102 A separate majority judgment, adopting different reasoning, was given by Lady Hale and Lord Mance.

${ }^{103} R$ (Evans) v Attorney General [2015] UKSC 21, [2015] A.C. 1787, [168].

104 For more detailed analysis of Evans, see M. Elliott, "A tangled constitutional web: The black-spider memos and the British constitution's relational architecture" [2015] P.L. 539. 
independent judicial tribunal: ${ }^{105}$ they were thus prepared to permit those factors to exert very substantial influence over their construction of the provision. In contrast, while they certainly did not neglect to recognise the other constitutional values in play, the dissentients placed primary emphasis upon the principle of parliamentary sovereignty - which they took, rightly or wrongly, to require much closer adherence to the literal meaning of the statutory text. While, therefore, one might paint the dissentients in Evans as having adopted a "formal" approach in that they gave priority to a plain-words reading of the legislation, they were moved to do so by what they considered to be the overriding normative pull of a particular constitutional principle.

Miller, however, is different. Whereas Evans was characterised by uncertainty and disagreement as to the application and interaction of readily identifiable - and identified constitutional principles, the majority judgment in Miller is characterised by opacity as to what, in the first place, the operative constitutional principles are. If, therefore, this is adjudication that is attentive to "substance" rather than "form", then it is attentive to substance only in a particular - and questionable - way. Indeed, in the final analysis, the majority's approach lapses into what might more accurately be dubbed instinctual, as distinct from substantive, constitutional adjudication. Such adjudication can properly be described as substantive only if it identifies and grapples with the substance of the pertinent constitutional principles. But that, as we have seen, is precisely what the majority fails to do, preferring instead to fall back on propositions that (on the one hand) assert requirements that are said to derive from constitutional principles but which (on the other hand) are too abstracted from those principles to amount to meaningful engagement with them.

Constitutional adjudication that is substantive in the sense that it draws upon, applies and develops constitutional principle is perfectly legitimate, provided that any associated curial innovation is respectful of the parameters which that self-same constitutional principle sets in relation to the judicial role. But there is a further, and fundamental, proviso. Seeing the wood as well as the trees is all well and good - but that does not licence judges to reimagine the constitutional landscape without adequate reference to the component principles of which that landscape is made up. Indeed, to adopt the sort of approach that the majority took in Miller is not simply normatively dubious, it is prudentially unwise. The courts' best defence against charges of improper activism lies in the accountability afforded by the discipline of giving rigorously reasoned judgments - a discipline that is all the more important when the stakes are as high as they were in Miller. A substantive, rather than a formal, approach to constitutional adjudication is wholly acceptable provided that it remains within these parameters. But it becomes both objectionable and imprudent if it is pursued in the intellectually lackadaisical manner that characterises the majority's reasoning in Miller.

105 The Upper Tribunal is designated a superior court of record by the Tribunals, Courts and Enforcement Act 2007, s. 3(5). 


\section{MILLER'S LEGACY}

By way of conclusion, it is worth asking what, in due course, Miller's legacy might turn out to be - a question that is highly sensitive to the perspective from which it is asked. Five such perspectives - from the exclusively political, through the narrowly legal, to the broadly constitutional - might usefully be considered.

First, as far as the politics of Brexit are concerned, Miller barely registers. For a short time during the autumn and winter of 2016-17, the Miller litigation appeared, at least to some ardent Remainers, to have the capacity to derail, delay or at least influence the course of Brexit. But Parliament's supine response once the ball had been put in its court by the Miller judgment put paid to any such ideas.

Second, however, Miller's implications for the wider constitutional politics of the UK cannot be written off as easily. Of course, it is primarily Brexit itself that produces such implications, given the way in which the referendum laid bare the divergent constitutional futures preferred by the peoples of the UK's four constituent nations. But Miller is relevant too, not least for the way in which it so fulsomely embraces the distinction between the constitutional realm's legal and political dimensions, thereby throwing into especially sharp relief the tension between the legal doctrine of parliamentary sovereignty and the quasi-federal political-constitutional structure of the modern UK. The latter finds its clearest expression in the Sewel convention - but the Court, as we have seen, refused to have any truck with it.

Third, in legal terms, Miller evidently has implications for the scope of the royal prerogative. But precisely what those implications are - and exactly how far they extend is unclear. If the newly minted category of things that cannot now be accomplished using prerogative power does not extend (much) beyond making constitutional changes as farreaching as leaving the EU, then the future significance of Miller in this regard will be approximately nil. But the judgment's implications will necessarily be greater if that category is wider - something that turns upon the as-yet hard-to-discern reach of the majority's "scale" principle. Reading between the lines of the majority judgment, the impression is conveyed that that principle is liable to bite only in highly constricted circumstances, even if those circumstances are not precisely coterminous with withdrawal from the EU. But the very vagueness of the principle - a phenomenon that is compounded by its unarticulated normative underpinnings - makes it unwise to attempt to offer any firm prediction as to its precise reach.

A fourth perspective from which Miller's significance can be examined pertains to the constitution's conceptual and doctrinal architecture. The interaction of EU and UK law amounts to a unique laboratory in which there is at least the potential of glimpsing the inner workings of the constitution at especially close quarters. Of course, the specific questions with which Miller was concerned will likely become moot once the UK leaves the EU. But the way in which those questions fall to be answered has at least the potential to be of more enduring relevance, given the answers' capacity to illuminate axiomatic issues. After all, how we account for the effect and status of EU law within the domestic legal system ought to tell us something profound about that system's nature. Here, however, Miller has little to offer, thanks to the majority's incoherent analysis of the relationship between EU and domestic law. If, as is probable, Miller was the UK apex court's last substantial opportunity to draw constitutional lessons of lasting relevance from the UK's European sojourn, it is an opportunity that went unrealised. 
Fifth, and finally, Miller can - and must - be evaluated by reference to its wider implications for constitutional adjudication. Viewed from this vantage point, Miller serves as a reminder of how acutely sensitive the outcome of constitutional adjudication can be to the identification and construction of the constitutional principles that form the lens through which the relevant legal issues fall to be examined. It is as a result of that sensitivity that (for example) the majority's analysis might be considered either a triumph of constitutional progressivism or a defence of an anachronistically bilateral conception of a newly multilateral politicalconstitutional order. Which of those views of the judgment is preferable is a contestable question. What is less open to debate is the fact that the very contestability of the principles that were in play in Miller - and which are often in play in hard constitutional cases — places judges under a heavy burden to adopt an analytically robust and transparent approach when it comes to deciding such cases. The Miller majority signally failed to discharge that burden — signalling, perhaps, that no such burden was perceived, and that painting with the broadest of curial brushes is considered acceptable. If that is so, then Miller's most significant legacy may prove to be one of adjudicative mode rather than constitutional substance (albeit that the two are inevitably intertwined to some extent). But if that is Miller's potential, then it is a potential that must go unrealised if constitutional adjudication is to avoid assuming a palmtree character that would risk robbing it of political legitimacy.

The notion that Miller represents the triumph of substance over form yields a superficially appealing narrative. But it is a narrative that is not sustainable. A legitimately substantive mode of constitutional adjudication must be not equated with the sort of inchoate instinctualism that characterised the judgment of the majority. Nor should analytical rigour be mistaken for arid formalism. Miller's legacy might prove to extend to the conflation of such matters, and the resultant licensing of a newly muscular (yet crude) form of constitutional adjudication. It is to be hoped, however, that the deficiencies of the majority judgment will instead serve as a salutary reminder of the imperative need to marry the rhetoric of constitutional principle with the intellectual endeavour that its application and development properly entails. 